\title{
PENAMPILAN SEPULUH VARIETAS KEDELAI YANG DITUMPANGSARIKAN DENGAN TEBU
}

\author{
Iskandar Umarie ${ }^{1^{*}}$, M. Hazmi ${ }^{1}$, Oktarina ${ }^{1}$ \\ ${ }^{1}$ Program Studi Agroekoteknologi, Fakultas Pertanian, Universitas Muhammadiyah Jember \\ * Corresponding Author : iskandarumarie@unmuhjember.ac.id
}

\begin{abstract}
[PERFORMANCES OF TEN SOYBEAN VARIETIES AS INTERCROPPED WITH SUGARCANE]. An intercropping system between soybean and sugarcane may be an alternative to increase soybean production in Indonesia, but not all soybean varieties are suitable for intercropping system as different soybean varieties may perform differently under intercropping system and monoculture system. Therefore, suitable soybean varieties for intercropping should be identified to warrant the higher crop productivity. This study was conducted to to compare the growth and yield performances of ten soybean varieties in monoculture and soybean-sugarcane intercropping systems. The experiment was laid in a Split Plot Design with three replications. The cropping systems (monoculture and intercrop) were allotted in the main plots, while the soybean varieties (Gepak Kuning, Kaba, Wilis, Tanggamus, Burarang, Sinabung, Anjasmoro, Agromulyo, Ring-1, and Gema) were assigned as the sub plots and allotted randomly in each main plot. On overall, the intercropping system had significantly reduced the soybean pod number, seed number, wight of 100 seed, and, seed yield/plant, but increased plant height as compared to the monoculture system. The exceptions were observed for seed number and weight of 100 seed. The reduction of seed number was not significant on Agromulyo and Dering-1.On the other hand, Anjasmoro and Dering-1were the only varieties showed significant reduction in weight of 100 seed. Kaba, Willis, Tanggamus, Burarang, Sinabung, and Dering- 1 showed their consistant performormances across the cropping systems. However, the higher seed yield/plant in both systems was observed on Gepak Kuning, Willis, Burarang, Agromulyo, Dering-1, and Gema.
\end{abstract}

Keyword: intercropping, monoculture, soybean, sugarcane

\begin{abstract}
ABSTRAK
Tumpangsari antara kedelai dan tebu dapat menjadi alternatif peningkatan produksi kedelai di Indonesia. Namun tidak semua varietas kedelai sesuai untuk diproduksi secara tumpangsari, karena varietas yang berbeda dapat memiliki penampilan yang berbeda ketika ditanam dalam sistem tumpangsari dan sistem monokultur. Karena itu, varietas kedelai yang sesuai untuk sistem tumpangsari perlu diidentifikasi untuk menjamin produktifitas tanaman yang tinggi. Penelitian ini bertujuan untuk membandingkan penampilan pertumbuhan dan hasil sepuluh varietas yang kedelai yang dibudidayakan dalam sistem monokultur dan sistem tumpangsari kedelai-tebu. Percobaan disusun dalam rancangan petak terbagi dengan tiga ulangan. Pola tanam (sistem monokultur dan sistem tumpangsari) ditempatkan sebagai petak utama, sedangkan varietas kedelai (Gepak Kuning, Kaba, Wilis, Tanggamus, Burarang, Sinabung, Anjasmoro, Agromulyo, Ring-1, and Gema) ditempatkan sebagai anak petak yang dialokasikan secara acak pada tiap petak utama. Secara umum, kedelai yang ditumpangsarikan dengan tebu secara nyata mengalami penurunan jumlah polong, jumlah biji, bobot 100 biji. dan hasil biji/tanaman tetapi tanamannya menjadi lebih tinggi dibanding kedelai yang ditanam secara monokultur. Pengecualian dijumpai pada jumlah biji dan bobot 100 biji. Untuk jumlah biji, hanya Agromulyo dan Dering-1 yang tidak mengalami penurunan secara signifikan. Sebaliknya, untuk bobot 100 biji, hanya Anjasmoro dan Dering-1yang mengalami penurunan secara nyata. Kaba, Willis, Tanggamus, Burarang, dan Sinabung menunjukkan penampilan pertumbuhan dan hasil yang konsisten ketika dibudidayakan secara monokultur maupun secara tumpangsari dengan tebu. Namun demikian, hasil biji/tanaman yang tinggi pada kedua pola tanam diperoleh dari Gepak Kuning, Willis, Burarang, Agromulyo, Dering-1, dan Gema.
\end{abstract}

Kata kunci: tumpangsari, monokultur, kedelai, tebu 


\section{PENDAHULUAN}

Kedelai merupakan komoditas pangan penting di Indonesia. Kebutuhan kedelai dalam negeri cukup besar dan selalu meningkat setiap tahunnya sehingga upaya mencukupi kebutuhan komoditas tersebut perlu terus dilakukan. Data produksi kedelai 2015 yang dikeluarkan Kementerian Pertanian, mencapai 998.870 ton, sedangkan kebutuhan masyarakat mancapai 2,54 juta ton. Dengan demikian, pada tahun tersebut Indonesia mengalami defisit produksi kedelai sekitar 1,54 juta ton (Balitbangtan, 2016).

Jawa Timur merupakan provinsi penyumbang terbesar produksi kedelai nasional, yaitu sebesar 36\% dengan luas panen 208.067 ha (BPS, 2016). Upaya peningkatan peroduksi kedelai di Jawa Timur melalui pembukaan areal baru semakin sulit dilakukan karena ketersediaan lahan yang terbatas. Namun demikian, perluasan areal panen masih dimungkinkan melalui optimasi pemanfaatan lahan-lahan perkebunan tebu dalam bentuk sistem tumpangsari. Luas lahan perkebunan di Jawa Timur mencapai 169.317 ha (APTRI, 2016) dan jika lahan-lahan tersebut juga dimanfaatkan untuk budidaya kedelai dengan pola tumpangsari, maka hasil yang diperoleh akan memberi sumbangan yang cukup besar terhadap produksi kedelai di Jawa Timur.

Tumpangsari merupakan penanaman secara bersama-sama antara dua atau tiga tanaman pada musim dan lahan yang sama. Program tumpangsari ini diyakini akan menjadi daya tarik tersendiri bagi petani karena dengan panen kedelai petani bisa menutupi biaya perawatan tebu sebelum tebu dipanen, hal dikarenakan Nisbah Kesetaraan Lahan (NKL) tumpangsari tebu-kedelai lebih dari 1,0 (Umarie \& Widiastuti, 2012). Program pengembangan tumpang sari tidak hanya membantu produksi gula, tetapi akan membantu pemenuhan kebutuhan kedelai dalam negeri, sehingga ketergantungan akan kedelai impor bisa dikurangi. Program ini lebih menguntungkan bagi petani, karena petani yang ingin membuka lahan tebu tidak mengalami kesulitan dalam memenuhi kebutuhan hidup sampai masa panen tebu.

Kedelai yang ditumpangsarikan dengan tebu pada lahan keprasan dapat meningkatkan efisiensi penggunaan lahan dengan NKL lebih besar dari 1,0 (Umarie \& Suroso, 2013; Umarie \& Suroso, 2014). Hal ini menunjukkan bahwa bahwa penanaman tumpangsari tebu-kedelai memberikan harapan yang besar untuk berkontribusi dalam peningkatan produksi kedelai secara nasional. Namun demikian, tidak semua varietas kedelai sesuai untuk ditumpangsarikan dengan tebu (Zeng et al. 2008; Daga, 2013 ; Rifai et al., 2014). Karena itu, pemilihan varietas-varietas kedelai yang sesuai untuk dibudidayakan secara tumpangsari perlu diidentifikasi. Tujuan penelitian ini adalah untuk membandingkan penampilan pertumbuhan dan hasil sepuluh varietas kedelai yang dibudidayakan dalam sistem monokultur dan sistem tumpangsari tebukedelai.

\section{METODE PENELITIAN}

Penelitian ini dilaksanakan di kebun percobaan Fakultas Pertanian Universitas Muhammadiyah Jember, dimulai dari Oktober 2016 sampai Januari 2017. Percobaan dilakukan dalam bentuk percobaan lapangan yang mengunakan rancangan petak petak terbagi. Sebagai petak utama adalah pola tanam (monokultur dan tumpangsari tebu-kedelai), sedangkan sebagai anak petak adalah varietas kedelai yang terdiri atas 10 varietas kedelai (Gepak Kuning, Kaba, Wilis, Tanggamus, Burarang, Sinabung, Anjasmoro, Agromulyo, Dering-1, dan Gema).

Pelaksanaan penelitian diawali dengan pembersihan lahan penelitian terlebih dahulu dari bekas tanaman sebelumnya kemudian tanah diolah menggunakan hand traktor. Pengolahan kedua dengan pembuatan bedengan sebanyak 30 petak. Ukuran masing-masing bedengan $3 \mathrm{~m} \times 1 \mathrm{~m}$ dengan jarak antar bedengan 0,3 dan jarak antar blok 0,5. Penanaman dilakukan dengan jarak tanam $25 \mathrm{~cm}$ antar baris tanaman x $20 \mathrm{~cm}$ antar tanaman, Setiap lubang tanam ditanami lima benih kedelai dan dibiarkan tumbuh sebanyak tiga tanaman/ lubang. Pemupukan tebu menggunakan TSP sebanyak $150 \mathrm{~kg} / \mathrm{ha}, \mathrm{KCl} 100 \mathrm{~kg} / \mathrm{ha}$ sebagai pupuk dasar dan pupuk ZA sebanyak $400 \mathrm{~kg} / \mathrm{ha}$ yang diberikan 2 minggu setelah tanam (mst) dan $300 \mathrm{~kg} / \mathrm{ha} 5 \mathrm{mst}$. Pemupukan kedelai menggunakan Urea sebanyak 25 $\mathrm{kg} / \mathrm{ha}$, TSP $100 \mathrm{~kg} / \mathrm{ha}$ saat tanam dan pupuk lanjutan menggunakan Urea sebanyak $25 \mathrm{~kg} / \mathrm{ha}, \mathrm{KCl} 75 \mathrm{~kg} / \mathrm{ha}$, diberikan 21 hari setelah tanam. Panen dilakukan apabila tanaman telah masak yaitu polong 95\% berwarna kuning, dan ditandai dengan rontoknya daun (terdapat 5-6 daun).

Variabel pengamatan terdiri atas tinggi tanaman, jumlah cabang/tanaman, jumlah buku pada batang utama, umur berbunga, jumlah polong/tanaman, jumlah biji/tanaman, bobot $100 \mathrm{biji}$, bobot biji/ tanaman. Data tinggi tanaman, jumlah cabang, jumlah buku, umur berbunga, jumlah polong, jumlah biji, bobot 100 biji, dan bobot biji dilakukan analisis varian (Anava), serta uji perbandingan berganda dengan menggunakan uji beda nyata terkecil dengan $\alpha=0,05$.

\section{HASIL DAN PEMBAHASAN}

\section{Penampilan pertumbuhan vegetatif tanaman}

Hasil analisis varian menunjukkan bahwa pola tanam berpengaruh nyata terhadap tinggi tanaman kedelai, tetapi tidak nyata terhadap jumlah cabang 
dan buku subur (Tabel 1). Secara umum, tanaman kedelai yang ditanam pada sistem tumpangsari dengan tebu memiliki tinggi tanaman yang lebih tinggi bila dibandingkan dengan tanaman kedelai yang ditanam secara monokultur. Upaya tanaman untuk meningkatkan penyerapan cahaya pada sistem pertanaman tumpangsari dilakukan dengan cara pemanjangan batang. Hal ini dikarena tanaman tidak mampu menaikkan daunnya ke atas kanopi. Umarie \& Suroso. (2013 dan 2014) menyatakan bahwa tumpangsari kedelai-tebu dapat menyebabkan meningkatnya tinggi tanaman kedelai. Hasil penelitian Reskynawati (2015) juga menunjukkan pemberian naungan 50\%-55\% pada tanaman kacang hijau memberikan pengaruh berupa pertambahan tinggi tanaman dibandingkan dengan tanaman kacang hijau yang ditanam pada kondisi cahaya yang penuh. Pada tanaman yang ternaungi akan menurunkan jumlah daun, daun menjadi lebih tipis, dan lebih lebar. Tanaman yang tumbuh pada lingkungan yang gelap akan tumbuh menjadi tinggi, kurus, dengan jarak antar buku yang panjang, dan relatif memiliki jumlah daun yang sedikit (Mulyana, 2006; Anggraeni 2010). Intensitas radiasi surya sangat mempengaruhi proses fotosintesis, dan untuk pertumbuhan optimum setiap jenis tanaman membutuhkan intensitas radiasi yang berbeda-beda (Kramer, 2012). Hasil penelitian Reskynawati (2015) menunjukkan bahwa tanaman kacang hijau yang ternaungi batangnya akan tumbuh lebih panjang dari pada daun dari tanaman yang ditanam pada cahaya penuh sebagai akibat dari usaha untuk mendapatkan cahaya.

Tabel 1. Rata-rata tinggi tanaman, jumlah cabang, dan jumlah buku subur tanaman kedelai pada dua pola tanam

\begin{tabular}{l|c|c|c}
\hline \multirow{2}{*}{ Pola tanam } & $\begin{array}{c}\text { Tinggi } \\
\text { Tanaman }\end{array}$ & Jumlah & Jumlah \\
\cline { 2 - 4 } & $(\mathrm{cm})$ & Cabang & $\begin{array}{c}\text { Buku } \\
\text { Subur }\end{array}$ \\
\hline Monokultur & $98,533 \mathbf{a}$ & 4,487 a & 15,120 a \\
\hline Tumpangsari & $104,293 \mathbf{b}$ & 4,327 a & $14,560 \mathbf{a}$ \\
\hline
\end{tabular}

Keterangan : Angka-angka pada kolom yang sama yang diikuti oleh huruf yang sama, berbeda tidak nyata berdasarkan uji BNT $(0.05)$.

Hasil analisis varian juga menunjukkan adanya perbedaan yang nyata antar varietas pada tinggi tanaman, jumlah cabang dan jumlah buku subur (Tabel 2). Anjasmoro merupakan varietas yang terpendek $(71,1 \mathrm{~cm})$, sedangkan Kaba, Willis, Tanggamus, Burarang, Sinabung, dan Dering-1, memiliki tinggi batang melebihi dari tingi rata-rata tanaman $(101,4$ $\mathrm{cm})$. Hasil tersebut mengambarkan ada enam varietas kedelai yang lebih toleran dalam keadaaan kondisi kekurangan cahaya akibat ternanung oleh tanaman tebu. Bertambahnya tinggi batang tanaman kedelai pada kondisi ternaung, dalam rangka penetrasi cahaya ke kanopi tanaman, merupakan proses adaptasi tanaman kedelai pada lingkungan yang tercekam. Chozin et al. (1999) menyatakan bahwa pada tanaman padi, bertambahnya tinggi pada tanaman di lingkungan yang ternaungi terdapat variasi antar genotipe. Umumnya genotipe peka memiliki kemampuan yang lebih kecil dalam meningkatkan pertambahan tinggi pada tanaman dibandingkan genotipe toleran. Perubahan morfologi dan anatomi daun terjadi dalam rangka meningkatkan efisiensi fotosintesis, seperti daun menjadi lebih tipis dan lebih lebar, sehingga jaringan penangkap cahaya menjadi lebih lebar (Evans \& Poorter, 2001).

Tabel 2. Rata-rata tinggi tanaman, jumlah cabang, dan jumlah buku subur tanaman pada sepuluh varietas kedelai

\begin{tabular}{|l|r|r|r|}
\hline \multicolumn{1}{|c|}{ Varietas } & $\begin{array}{c}\text { Tinggi } \\
\text { Tanaman } \\
\text { (cm) }\end{array}$ & $\begin{array}{c}\text { Jumlah } \\
\text { Cabang } \\
\text { (buah) }\end{array}$ & $\begin{array}{c}\text { Jumlah } \\
\text { Buku } \\
\text { Subur } \\
\text { (buah) }\end{array}$ \\
\hline Gepak Kuning & $96,0 \mathrm{~b}$ & $4,3 \mathrm{bcd}$ & $16,2 \mathrm{c}$ \\
\hline Kaba & $110,4 \mathrm{~d}$ & $4,3 \mathrm{bcd}$ & $15,8 \mathrm{c}$ \\
\hline Willis & $110,6 \mathrm{~d}$ & $4,0 \mathrm{abc}$ & $17,0 \mathrm{c}$ \\
\hline Tanggamus & $107,9 \mathrm{~cd}$ & $4,1 \mathrm{abc}$ & $16,2 \mathrm{c}$ \\
\hline Burarang & $109,7 \mathrm{~d}$ & $5,1 \mathrm{dc}$ & $12,7 \mathrm{a}$ \\
\hline Sinabung & $108,7 \mathrm{~cd}$ & $4,8 \mathrm{cde}$ & $15,9 \mathrm{c}$ \\
\hline Anjasmoro & $71,1 \mathrm{a}$ & $3,27 \mathrm{a}$ & $11,8 \mathrm{a}$ \\
\hline Agromulyo & $88,2 \mathrm{~b}$ & $4,9 \mathrm{cde}$ & $12,1 \mathrm{a}$ \\
\hline Dering-1 & $113,2 \mathrm{~d}$ & $3,8 \mathrm{ab}$ & $16,2 \mathrm{c}$ \\
\hline Gema & $98,3 \mathrm{bc}$ & $5,6 \mathrm{e}$ & $14,4 \mathrm{~b}$ \\
\hline \multicolumn{1}{|c|}{ Rata-rata } & 101,4 & 4,4 & 14,8 \\
\hline
\end{tabular}

Keterangan : Angka-angka pada kolom yang sama yang diikuti oleh huruf yang sama, berbeda tidak nyata berdasarkan uji BNT (0.05).

Berdasarkan jumlah cabang yang terbentuk, Anjasmoro merupakan varietas memiliki jumlah cabang yang paling sedikit, sedangkan Sinabung, Agromulyo, Burarang, dan Gema memiliki jumlah cabang melebihi dari cabang rata-rata tanaman. Keempat varietas tersebut memiliki kemampuan toleransi lebih baik dari varietas kedelai yang lainnya terhadap kondisi kekurangan cahaya akibat naungan. Perbedaan jumlah cabang pada varietas kedelai di atas sangat berkaitan erat dengan potensi genetik dan keragaman genetik dari masing-masing varietas. Hal ini menunjukkan karakter genetik setiap varietas 
berhasil mempertahankan stabilitas jumlah cabang pada kondisi ternaungi. Dengan kata lain, jumlah cabang sepuluh varietas pada penelitian ini, sangat dominan ditentukan oleh faktor genetik.

Berdasarkan jumlah subur yang dihasilkan tanaman, Anjasmoro merupakan varietas yang memiliki jumlah buku subur paling sedikit, sedangkan Willis memiliki jumlah buku subur terbanyak. Namun demikian terdapat enam varietas, yaitu Gepak Kuning, Kaba, Willis, Tanggamus, Sinabung, dan Dering-1, yang memiliki jumlah buku subur di atas rata-rata tanaman. Perbedaan jumlah buku subur pada varietas kedelai di atas sangat berkaitan erat dengan susunan genetik dan kemampuan beradaptasi dengan lingkungan dari masing-masing varietas. Mekanisme adaptasi tanaman kedelai terhadap kekurangan intensitas cahaya dapat dimaniferstasikan dengan penambahan dan pengurangan jumlah buku subur. Perubahan morfologi dan anatomi pada daun untuk memaksimalkan penangkapan cahaya agar terjadi efisiensi fotosintesis. Hal ini merupakan bentuk respons menghindar (shade avoidance response) pada tanaman yang mengalami cekaman intensitas cahaya rendah (Evans \& Poorter, 2001).

\section{Penampilan pertumbuhan generatif tanaman}

Analisis varian terhadap data pertumbuhan generatif menunjukkan bahwa pola tanam menghasilkan perbedaan nyata pada jumlah polong/tanaman, jumlah biji /tanaman, bobot 100 biji, dan bobot biji tanaman. Secara umum, tanaman kedelai yang ditanam pada sistem tumpangsari dengan tebu mengalami penununan jumlah polong, jumlah biji, bobot 100 biji, dan bobot biji/tanaman bila dibandingkan dengan tanaman kedelai pada budidaya monokultur. Terhambatnya proses metabolisme tanaman akibat intensitas cahaya rendah, menyebabkan berkurangnya jumlah biji per tanaman, jumlah polong/ tanaman, bobot 100 biji, dan bobot biji/tanaman. Hal tersebut berimplikasi penurunan jumlah pasokan fotosintat ke bagian organ biji sehingga terjadi penurunan jumlah polong per tanaman, jumlah biji/tanaman, bobot 100 biji, dan bobot biji/tanaman. Mathew et al. (2000), mengemukakan bahwa lingkungan tumbuh tumpangsari kedelai-tebu menyebabkan terjadinya penurunan produksi pada tanaman kedelai. Hal ini disebabkan karena berkurangnya intensitas cahaya yang diterima tanaman, keadaan tersebut biasanya terjadi pada fase generatif yang merupakan fase peka terhadap kekurangan cahaya sehingga polong mudah gugur. Dengan demikian, jumlah biji dan bobot biji/tanaman dapat mengalami penurunan (Chairudin et al., 2015; Umarie \& Widiarti, 2015; Widiarti \& Umarie, 2016).

Perbedaan yang nyata antar varietas dijumpai pada umur berbunga, jumlah polong, jumlah biji, bobot 100 biji, dan bobot biji/tanaman (Tabel 3).

Tabel 3. Rata-rata umur berbunga, jumlah polong, jumlah biji, bobot 100 biji, dan bobot biji/tanaman kedelai pada dua pola tanam

\begin{tabular}{|l|c|c|c|c|c|}
\hline Pola tanam & $\begin{array}{c}\text { Umur } \\
\text { berbunga } \\
\text { (hari) }\end{array}$ & $\begin{array}{c}\text { Jumlah } \\
\text { polong } \\
\text { (buah) }\end{array}$ & $\begin{array}{c}\text { Jumlah } \\
\text { biji (buah) }\end{array}$ & $\begin{array}{c}\text { Bobot 100 } \\
\text { biji (g) }\end{array}$ & $\begin{array}{c}\text { Bobot } \\
\text { biji/tanaman } \\
\text { (g) }\end{array}$ \\
\hline Monokultur & $37,2 \mathrm{a}$ & $44,3 \mathrm{a}$ & $81,8 \mathrm{a}$ & $10,047 \mathrm{a}$ & $7,603 \mathrm{a}$ \\
\hline Tumpangsari & $36,9 \mathrm{a}$ & $36,3 \mathrm{~b}$ & $57,8 \mathrm{~b}$ & $8,466 \mathrm{~b}$ & $4,640 \mathrm{~b}$ \\
\hline
\end{tabular}

Keterangan : Angka-angka pada kolom yang sama yang diikuti oleh huruf yang sama, berbeda tidak nyata berdasarkan uji BNT (0.05).

Interaksi pola tanam dengan varietas berpengaruh nyata pada jumlah biji dan bobot 100 biji. Argomulyo merupakan varietas yang memiliki umur berbunga tercepat, sedangkan Gepak Kuning memiliki umur berbunga terlambat. Namun demikian terdapat dua varietas, yaitu Agromulyo dan Gema, yang memiliki umur berbunga lebih cepat dari rata-rata varietas yang dievaluasi (Tabel 4). Berdasarkan jumlah polong yang dihasilkan, Anjasmoro merupakan varietas yang memiliki jumlah polong paling sedikit, sedangkan Gepak Kuning memiliki jumlah polong terbanyak. Terdapat lima varietas (Gepak Kuning, Willis, Burarang, Sinabung, dan Dering-1) yang memiliki jumlah polong di atas rata-rata.

Adanya pengaruh interaksi nyata antara pola tanam dan varietas kedelai pada jumlah biji dan bobot 100 biji menunjukkan bahwa varietas kedelai yang dievaluasi memiliki respon yang berbeda dalam pembentukan biji ketika dibudidayakan pada pola tanam berbeda. Secara umum, tumpangsari mengakibatkan penurunan kedua variabel tersebut, namun tingkat penurunannya bervariasi antar varietas (Tabel 5). Berdasarkan jumlah biji yang terbentuk, seluruh varietas mengalami penurunan yang nyata ketika dibudidayakan dengan pola tumpangsari, kecuali Agromulyo dan Dering-1 yang penurunannya tidak nyata. Tumpangsari juga menyebabkan penurunan bobot 100 biji, namun hanya Anjasmoro dan Dering-1 yang mengalami penurunan secara nyata.

Kemampuan varietas toleran menghasilkan produksi/tanaman yang lebih tinggi dari pada yang peka diduga karena kemampuannya dalam membentuk jumlah polong berisi yang lebih banyak dan kemampuannya mengefisenkan dalam memanfaatkan energi dari intensitas cahaya yang rendah. Penurunan laju respirasi di bawah titik kompensasi cahaya yang dilakukan dengan menghindari kerusakan enzim dan menghindari kerusakan pigmen, merupakan suatu cara tanaman mentolerir keadaan cahaya yang rendah. 
Tabel 4. Pengaruh varietas tumbuh, terhadap umur berbunga, jumlah polong, dan bobot biji tanaman sepuluh varietas kedelai

\begin{tabular}{|c|c|c|c|}
\hline Varietas & $\begin{array}{c}\text { Umur } \\
\text { berbunga } \\
\text { (hst) }\end{array}$ & $\begin{array}{l}\text { Jumlah } \\
\text { polong }\end{array}$ & $\begin{array}{c}\text { Bobot biji } \\
\text { tanaman } \\
(g)\end{array}$ \\
\hline Gepak Kuning & $39,433 \mathbf{e}$ & $73,833 \mathbf{d}$ & $8,527 \mathbf{d}$ \\
\hline Kaba & 37,667 cd & $35,533 \mathbf{b}$ & $5,580 \mathbf{b c}$ \\
\hline Willis & $38,267 \mathbf{d}$ & $42,300 \mathbf{b c}$ & $7,633 \mathbf{d}$ \\
\hline Tanggamus & 38,167 cd & $40,067 \mathbf{b c}$ & $5,630 \mathbf{b c}$ \\
\hline Burarang & $37,500 \mathbf{c d}$ & $44,900 \mathbf{c}$ & $7,650 \mathbf{d}$ \\
\hline Sinabung & $38,033 \mathbf{c d}$ & 41,667 bc & $5,190 \mathbf{b}$ \\
\hline Anjasmoro & $37,400 \mathbf{c}$ & 19,900 a & $3,573 \mathbf{a}$ \\
\hline Agromulyo & $32,767 \mathbf{a}$ & $25,033 \mathbf{a}$ & $5,850 \mathbf{b c}$ \\
\hline Dering-1 & 38,100 cd & $41,600 \mathbf{b c}$ & $6,170 \mathbf{c}$ \\
\hline Gema & $33,867 \mathbf{b}$ & 38,600 bc & $5,410 \mathbf{b c}$ \\
\hline Rata-rata & 37,12 & 40,343 & 6,121 \\
\hline
\end{tabular}

Keterangan : Angka-angka pada kolom yang sama yang diikuti oleh huruf yang sama, berbeda tidak nyata berdasarkan uji BNT $(0.05)$.

Tabel 5. Rata-rata jumlah biji dan bobot 100 biji dari sepuluh varietas kedelai yang dibudidayakan pada dua pola tanam

\begin{tabular}{|c|c|c|c|c|}
\hline \multirow{2}{*}{ Varietas } & \multicolumn{2}{|c|}{ Jumlah biji } & \multicolumn{2}{|c|}{ Bobot 100 Biji } \\
\hline & Monokultur & Tumpangsari & Monokultur & Tumpangsari \\
\hline $\begin{array}{l}\text { Gepak } \\
\text { Kuning }\end{array}$ & $147,800 \mathrm{dA}$ & 104,667 e B & 6,864 a A & $6,783 \mathrm{aA}$ \\
\hline Kaba & $77,133 \mathrm{bA}$ & $57,867 \mathrm{~cd} \mathrm{~B}$ & 9,366 bc $A$ & $7,682 \mathrm{ab} A$ \\
\hline Willis & $120,333 \mathrm{cA}$ & $64,467 \mathrm{~cd} \mathrm{~B}$ & $8,359 a b$ A & $8,172 a b A$ \\
\hline Tanggamus & $80,400 \mathrm{bA}$ & $60,533 \mathrm{~cd} \mathrm{~B}$ & 8,655 bc $A$ & $7,485 a b A$ \\
\hline Burarang & $72,333 \mathrm{bA}$ & 52,000 bc B & 13,102 de $A$ & $11,262 \mathrm{cA}$ \\
\hline Sinabung & $81,333 \mathrm{bA}$ & 51,067 bc B & 8,712 bc $A$ & $6,892 \mathrm{aA}$ \\
\hline Anjasmoro & 45,667 a A & 26,067 a B & $11,646 \mathrm{dA}$ & 7,458 ab B \\
\hline Agromulyo & 45,267 a A & $40,600 a b A$ & 14,351 e A & $12,782 \mathrm{cA}$ \\
\hline Dering-1 & $80,467 \mathrm{bA}$ & $70,067 \mathrm{~d} A$ & 9,472 bc A & $7,170 \mathrm{aB}$ \\
\hline Gema & $67,733 \mathrm{bA}$ & 50,667 bc B & $9,941 \mathrm{cA}$ & $8,977 \mathrm{bA}$ \\
\hline
\end{tabular}

Keterangan : Angka-angka pada kolom yang sama yang diikuti oleh huruf kecil yang sama dan angka-angka pada baris yang sama diikuti oleh huruf besar yang sama, berbeda tidak nyata berdasarkan uji BNT (0.05).

Trikoesoemaningtyas (2008) menyatakan bahwa kemampuan tanaman menyimpan karbohidrat dalam bentuk biji, sebagai manifestasi varietas yang memiliki daya tahan terhadap naungan. Pada fase reproduksi, penaungan dapat menyebabkan aktifitas fotosintesis berkurang dan alokasi fotosintat ke organ reproduksi juga menjadi berkurang. Hal ini desebabkan karena terjadi penurunan aktivitas fotosintesis di daun (Kakiuchi \& Kobata, 2004). Varietas-varietas toleran terhadap naungan akan mampu beradaptasi dengan baik dengan menyesuaikan laju fotosintesisnya, sehingga penampilan hasilnya (umur berbunga, jumlah polong, jumlah biji, bobot 100 biji, dan bobot biji/ tanaman) relatif stabil (Adisarwanto et al., 2000; Susanto \& Sundari, 2011; Umarie \& Widiarti, 2015; Widiarti \& Umarie, 2016).

\section{KESIMPULAN}

Secara umum, kedelai yang ditumpangsarikan dengan tebu secara nyata mengalami penurunan jumlah polong, jumlah biji, bobot 100 biji. dan hasil biji/ tanaman tetapi tanamannya menjadi lebih tinggi dibanding kedelai yang ditanam secara monokultur. Pengecualian dijumpai pada jumlah biji dan bobot 100 biji. Untuk jumlah biji, hanya Agromulyo dan Dering-1 yang tidak mengalami penurunan secara signifikan. Sebaliknya, untuk bobot 100 biji, hanya Anjasmoro dan Dering-1yang mengalami penurunan secara nyata. Kaba, Willis, Tanggamus, Burarang, dan Sinabung menunjukkan penampilan pertumbuhan dan hasil yang konsisten ketika dibudidayakan secara monokultur maupun secara tumpangsari dengan tebu. Namun demikian, hasil biji/tanaman yang tinggi pada kedua pola tanam diperoleh dari Gepak Kuning, Willis, Burarang, Agromulyo, Dering-1, dan Gema.

\section{SANWACANA}

Ucapan terimakasih disampaikan kepada Rektor Universitas Muhammadiyah Jember, c.q. Lembaga Penelitian dan Pengabdian Kepada Masyarakat (LPPM) yang telah memberikan pendanaan dalam penelitian ini pada anggaran tahun 2016/2017.

\section{DAFTAR PUSTAKA}

Adisarwanto, T., Suhartina, \& Soegiyatni. (2000). Respon kedelai terhadap beberapa tingkat naungan. Edisi Khusus Balitkabi, 16, 12-21.

Anggraeni, B.W. (2010). Studi morfo-anatomi dan pertumbuhan kedelai (Glycine max (L) Merr) pada kondisi cekaman intensitas cahaya rendah. Institut Pertanian Bogor, Bogor.

APTRI. (2016). Berita Harian Asosiasi Petani Tebu Rakyat Indonesia. Asosiasi Petani Tebu Rakyat Indonesia, Jakarta.

Balitbangtan. (2016). Target Nasional Produksi Kedelai tahun 2016. Badan Penelitian dan Pengembangan Pertanian, Jakarta. 
BPS. (2016). Tabel Dinamis Tanaman Pangan. Badan Pusat Statistik, Jakarta, https://www.bps.go.id/ site/resultTab.

Chairudin, Efendi, \& Sabaruddin. (2015). Dampak naungan terhadap perubahan karakter agronomi dan morfo-fisiologi daun pada tanaman kedelai (Glycine max (L.) Merrill). J. Floratek. 10, 26-35

Chozin, M.A., Sopandie, D., Sastrosumarjo, S., \& Suwarno. (1999). Physiology and genetic of upland rice adaptation to shade. Final Report of Graduate Team Research Grant, URGE Project. Directorate General of Higher Education, Ministry of Education and Culture, Jakarta.

Daga, S. (2013). Evaluation of soybean varieties under different planting patterns for intercropping in sugarcane at Finchaa Sugar Estate (Thesis). Haramaya University, Haramaya.

Evans, J.R.\& Poorter,H. (2001). Photosynthetic acclimation of plants to growth irradiance: the relative importance of specific leaf area and nitrogen partitioning in maximizing carbon gain. Plant Cell Environ, 24, 755-767.

Kakiuchi, J. \& Kobata, T. (2004). Shading and thinning effects on seed and shoot dry matter increase in determinate soybean during the seed-filling period. Agron. J., 96, 398-405.

Kramer, P. (2012). Physiology of woody plants. Elsevier.

Mathew, J.P., Herbert, S.J., Zhang, S., Rautenkranz, A.A.F. \& Litchfield, G.V. (2000). Different response of soybean yield component to the timing of light enrichment. Agron. J., 92, 11561161.

Mulyana, N. (2006). Adaptasi morfologi, anatomi, dan fisiologi empat genotip Kedelai (Glycine max (L.) pada kondisi cekaman naungan. Skripsi, Program Studi Agronomi. Fakultas Pertanian, IPB, Bogor.

Reskynawati, K. (2015). Pertumbuhan dan produksi tanaman kacang hijau (Vigna radiata L.) pada berbagai tingkat naungan. Skripsi, Program Studi Agroteknologi. Fakultas Pertanian, Universitas Hasanuddin, Makasar.

Rifai, A., Basuki, S., \& Utomo, B. (2014). Nilai kesetaraan lahan budi daya tumpangsari tanaman tebu dengan kedelai: Studi kasus di Desa Karangharjo,
Kecamatan Sulang, Kabupaten Rembang. Widyariset, 17(1), 59-69.

Sasmita, P., Purwoko, B.S., Sujiprihati, S., Hanarida, I., Dewi, I.S. \& Chozin, M.A. (2006). Evaluasi pertumbuhan dan produksi padi gogo haploid ganda toleran naungan dalam sistem tumpang sari. Bul. Agron., 34, 79-86.

Susanto, G.W.A. \& Sundari, T. (2011). Perubahan karakter agronomi aksesi plasma nutfah kedelai di lingkungan ternaungi. J. Agron. Indonesia, 39 (1), 1-6 .

Soverda, N. (2015). Studi Karakteristik Fisiologi Tanaman Kedelai Toleran Terhadap Naungan. Artikel Ilmiah. Jurusan Agroekoteknologi, Fakultas Pertanian, Universitas Jambi, Jambi.

Trikoesoemaningtyas. (2008). Uji Daya Hasil Galurgalur Kedelai Toleran Naungan Hasil Seleksi Marka Morfologi dan Molekuler. Laporan Akhir Hibah Penelitian LPPM dan Sekretariat BPPP. Institut Pertanian Bogor, Bogor.

Umarie, I. \& Widiarti, W. (2012). Pengujian berbagai paket teknologi budidaya pada sistem tanaman tumpangsari tebu dan kedelai. Agritrop, 10(2), 126-133.

Umarie, I. \& Suroso, B. (2013). Pengujian Berbagai Paket Teknologi Budidaya Pada Sistem Tanaman Tumpangsari Tebu dan Kedelai Pada Lahan Keprasan. Laporan PHB DIKTI, Tahun Pertama.

Umarie, I. \& Suroso, B. (2014). Pengujian Berbagai Paket Teknologi Budidaya Pada Sistem Tanaman Tumpangsari Tebu dan Kedelai Pada Lahan Keprasan. Laporan PHB DIKTI, Tahun Kedua.

Umarie, I. \& Widiarti, W. (2015). Analisis Karakteristik Morfo-Fisiologis Tanaman Kedelai (Glycine max L.) Pada Sistem Tumpangsari Tebu-Kedelai. Laporan Penelitian Fundamental DIKTI, Tahun Pertama.

Widiarti, W. \& Umarie, I. (2016). Analysis of soybean (Glycine $\max$ L.) morfo-physiological characteristics on sugarcane-soybean intercropping system. Conference Proceeding, the 2nd International Conference on Food Agriculture, and Natural Resources, 673-692.

Zeng, W. Y., Liang, J., Chen, Y., \& Ma, H. B. (2008). Yield analysis of different spring soybean varieties intercropped with sugarcane. Guangxi Agricultural Sciences, 6, 008. 